\title{
A Study to Examine Time-Varying Effectiveness of Stock Returns on Tehran Stock Exchange
}

\author{
Rahele SiamiNamini ${ }^{1}$, Fereydoun RahnamaRoudposhti ${ }^{2} \&$ Mohammad.H Janani ${ }^{2}$ \\ ${ }^{1}$ Department of Financial Management, Science and Research Branch, Islamic Azad University, Tehran, Iran \\ ${ }^{2}$ Islamic Azad University, Central Branch, Tehran, Iran \\ Correspondence: Rahele SiamiNamini, M.Sc Student in Financial Management, Department of Financial \\ Management, Science and Research Branch, Islamic Azad University, Tehran, Iran. E-mail: rahele59@yahoo.com
}

Received: October 13, 2012

Accepted: March 4, 2013

Online Published: April 8, 2013

doi:10.5430/ijfr.v4n2p154

URL: http://dx.doi.org/10.5430/ijfr.v4n2p154

\begin{abstract}
The present study aims to examine the presence of various anomalies or 'calendar effects' in stock index returns by using the Tehran Stock Exchange (TSE) index during the period 2004-2010.

The findings show that the weekend effect, the weekend effect within the monthly effect, the monthly effect, and seasonal effect are present in the return equations of $\mathrm{GARCH}_{(1,1)}, \mathrm{GARCH}-\mathrm{M}$, and Modified $\mathrm{GARCH}_{(1,1)}$ models.

Analyzes the weekend effect, and also the weekend effect in the first half and the second half of the month; this study finds a weekend effect: Wednesday's returns are significantly greater than Saturday's returns. However, the spread of returns on Wednesday and Saturday will be vary between the first half and the second half of the month.

There are also monthly effects on excessive returns in Farvardin (March 20- April 19), Mordad (July 22- August 21) and Shahrivar (August 22- September 21), and on negative returns in Mehr (September 22- October 21) and Esfand (February 19- March 19) in the Tehran Stock Exchange. In terms of the seasonal effect, the study reveals that the highest rate of return can be achieved in the summer, while the lowest rate is appeared in the winter.
\end{abstract}

Keywords: weekend effect, monthly effect, seasonal effect, $\mathrm{GARCH}_{(1,1)}$ model, GARCH-M model, modified GARCH $_{(1,1)}$ model

\section{Introduction}

Thaler (1993) believes that the modern financial management regards individuals and financial markets in an immovable and inflexible manner with a mere mathematical logic. While ignoring humankind as the primary parameter within the financial markets who has certain characteristics, attitudes and psychological feelings and faces many different barriers in making logical and intellectual decisions; the modern financial management deals with theorizing on capital markets so that such a closed mindedness could not describe capital markets well. Therefore, strength and firmness of efficient markets which increased between the 1970's and the 1990's of the last century gradually decline due to inconsistent evidences and experimental anomalies found. On the other hand, the Capital Asset Pricing Model (CAPM) has been put into question. The validity of systematic risks as the key determinant of returns becomes discolored and a novel school to financial knowledge shades financial scholars and capital markets.

Balaban (1994) claims that the periodic effect is one of the predictable patterns in stock returns that can be exploited to gain excessive returns and may challenge the efficient market hypothesis (EMH). Some experimental tests have shown that using specific trading patterns based on different times (day, month and year) can provide excessive returns. Hence, the calendar and periodic effects are considered as the main predictors of future stock behavior.

The most common calendar anomaly in world financial markets is the monthly effect; it implies that the mean return for stock depends upon the month of the year there is. The main result of experimental studies indicates the higher return in January than other months of the year. This can be justified by releasing tax statements in December that leads to recognize funds a company can provide for investment. For factors causing the January effect, Haugen and Lakonishok (1988) refer to a selling pressure for shares of poor performance at the year end, because such losses are reported on the tax return. When the pressure removed, these shares will be traded in the January prices. Also, the 
authors state that at the beginning of a new year, many investment managers get involved in new combinations of their portfolio items, which can, in turn, disturb the market.

The semi-monthly (intra-month) effect reflects the changes in return within a month as the days elapse. Research indicates higher returns on the early days than the rest of the month. Higher liquidity on the early days of a month and also earnings announcements are the reasons scholars concern for such phenomenon.

The summer effect is one of the first calendar effects took an interest of researchers and financial analysts. Vachel (1942) finds some evidences of higher growth rates for stock prices during the summer rather than other seasons.

The day of the week effect involves patterns in stock returns on the last days related to, in particular, special days in a week. The presence of such relationship has been confirmed at the US, so that the last trading day of the week has abnormal positive returns. While, the early trading day of the week shows a lower - even negative- returns than other days. The effect is an evidence for the claim that stock returns on different days of a week are not dependent. This is inconsistent with the random walk theory, since it refers to predictability of stock returns on different days of a week.

The current study investigates effects of time on stock returns, by using the time variable, weekend effect, weekend effect within the monthly effect (in the first half and in the second half of the month), monthly effect, and seasonal effect. The main question is that whether asymmetric relationship is present between above-mentioned times on the Tehran Stock Exchange. If so, does it follow a certain pattern? And, what are the potential causes?

\section{Literature Review}

Studies in time efficiency have found seasonality (January Effect), day of the week effect and intra-monthly patterns in both domestic markets and international markets.

The literature on monthly effects, generally, confirmed the January and year-end effect, which is related to tax-loss selling strategies and behavioral aspects.

The very first evidence found for the existence of January effect is that of Watchel (1942). He studied US stock market and found that returns in January are relatively higher After that Rozeff and Kinney (1976) demonstrated that stock returns of the New York Stock markets are in first 15 days of the January are significantly larger than rest of year. Other major capital markets in developed countries exhibit similar calendar effects: Officer (1975) focused on the Australian Stock Exchange; Tinic, Barone-Adesi and West (1990) on the Canadian market; Aggarwal, Rao and Hiraki (1990) on the Tokyo Stock Exchange; Barone (1990) on the Italian market and Lewis (1989) analyzed stocks listed on the London Exchange. The literature on the so-called disposition effect \{that losers are hold too long and winners are sold to early\} also refers to a year-end effect (see Odean, 1998).

Wong,Ho, Dollery (2007) investigated the monthly effect in Malaysian stock Market for period 1994-2006 by partitioning data into 3 sub-periods. Their results revealed the existence of monthly effect in different periods but not on the whole such as February effect was there in pre-crisis period and January effect in post-crisis period. Bahadur and Joshi (2005) proved persistent Month of the year anomaly for Nepalese Stock Exchange for period 1995-2004. Chia'et al (2006) also conducted a study on Malaysian Stock Exchange and confirmed no January effect or any other monthly effect exists.

Thomas (2002) also found a significant Month of the year effect in Swedish Stock market for period 1987-1996. Agathee (2008) showed lowest average returns in March and highest average returns in month of June for Mauritian Stock Exchange. Gao and Kling (2005) reported strong year end effect in 1991 which disappeared later. In Shanghai and Shenzhen, with February as yearend, high returns can be observed in March and April.

A recent study conducted by Imad .A. Moosa (2007) by using monthly average returns on U.S.Stocks for period of 1970 to 2005 reveals that a significant January effect existed except for the period 1990-2005 where negative July effect dominated.

One explanation of the higher returns in January is the tendency to realize losses in December to reduce the taxable speculation gains. Another effect is window dressing, which is related to institutional trading. To avoid reporting to many losers in their portfolios at the year-end, institutional investors tend to sell losers in December. They buy these stocks after the reporting date in January to hold their desired portfolio structure again. This yields higher returns in January compared to other months.

Additionally, empirical investigations have provided convincing evidence that there are day of the week effects on stock market returns. Cross (1973) found that the mean return on Friday was higher than the mean return on Monday of the S\&P 500 Index during the period from 1953 to 1970. This effect is usually called the weekend effect. French (1980) who also investigated the S\&P 500 index verified this finding for the period from 1953 to 1977. Later, 
Gibbons and Hess (1981) and Smirlock and Starks (1986) reported similar results. The day of the week effect is also observed in stock markets of other countries. Jaffe and Westerfield (1985) examined the weekend effect in Australian, Canadian, Japanese and UK equity markets, and found that the lowest mean returns for both Japanese and Australian stock markets were on Tuesdays. Solnik and Bousquet (1990) also demonstrated a strong and persistent negative return on Tuesday in the case of the Paris Bourse. Barone (1990) confirmed these results that identified the largest decline in Italian stock prices mostly on Tuesday. Afterwards, Agrawal and Tandon (1994), Alexakis and Xanthakis (1995), and Balaban (1995) showed that the distribution of stock returns varies dependent on the respective day of the week for various countries. Moreover, the day of the week patterns are present in other US financial markets including the T-bill market (Flannery and Protopapadakis, 1988), the commodity and stock futures markets (Cornell, 1985; Dyl and Maberly, 1986; Gay and Kim, 1987). Brooks and Persand (2001) confirmed that both Thailand and Malaysia had significant negative Tuesday returns, and Taiwan had a significant Wednesday effect.

In brief, the day of the week effect is a common phenomenon across different countries and different types of markets.

Studies have also been done to determine if there is an intra-monthly anomaly. Ariel documents a monthly pattern in United States stock index returns. Stocks were found to earn a positive average return in the beginning and during the first half of calendar months and zero average returns during the second half. A weak monthly effect has also been observed in foreign countries (Jaffe and Westerfield 1989). Australia, United Kingdom and Canada had patterns consistent with Ariel's findings in the United States. Japan, however, had an inverse effect. There remains a need in our fast changing global economy for a study of the monthly effect for international markets for which analyses are incomplete.

\section{Sample Selection and Time Period}

Due to limitations in Iranian financial markets (money, currencies, commodities, etc.); the research population is restricted to the Tehran Stock Exchange (TSE). Formality, comprehensiveness, and data validity are the main features of this population. The study includes the TSE's Price and Dividend Index (TEDPIX). In order to calculate daily returns, data was gathered during the period of 2004-03-27 to 2010-03-18. It should be noted that official calendar in Iran is Solar Hijri, so all the names of days, months, and years are used according to the official Persian calendar.

\section{Research Methodology}

The study is a descriptive-correlational research based on the observation. First, time series data was collected for the period 2004-03-27 to 2010-03-18. Next, model parameters were analyzed by using Eviews software.

Statistical and econometric methods were applied to evaluate and examine the research hypotheses. By running regressions on dummy variables for given periods, the regression coefficients were estimated through three GARCH $_{(1,1)}$, GARCH-M and Modified GARCH models. Then, the level of significance test was conducted.

\section{The Empirical Findings}

Tables 1 to 3 show the results obtained from the descriptive statistical techniques used to evaluate time-varying effects on stock returns at the TSE. The last three columns in each table include the findings for different estimation models; namely, $\mathrm{GARCH}_{(1,1)}, \mathrm{GARCH}-\mathrm{M}$, and Modified $\mathrm{GARCH}_{(1,1)}$. Note that the Durbin-Watson test statistic is about 2.0 for all estimations, indicating the lack of self-correlation in research models. Also according to the estimation coefficient resulted, about $18 \%$ changes in the dependent variable can be justified by the independent variable.

\subsection{Weekend Effect}

Table 1 shows the regression results for stock returns on two days before and after the weekend at the TSE for the period being studied. As seen in Table 1, regression coefficients stay significant, positive for Saturday's and Wednesday's variables. Also, the return variable has a significant, positive effect on return over the same period with just one break. Therefore, it is clear that Wednesday, as the last working day, will have a positive effect on the stock market and lead to higher return than Saturday. Furthermore, the result reveals that Saturday, as the first working day after the weekend, will also have a significant, positive effect on the TSE. 
Table 1. Weekend effect

\begin{tabular}{|c|c|c|c|c|}
\hline & & $\operatorname{GARCH}(1,1)$ & GARCH-M & $\begin{array}{l}\text { MODIFIED } \\
\text { GARCH }(1,1)\end{array}$ \\
\hline \multirow{9}{*}{$\begin{array}{l}\text { Return } \\
\text { Equation }\end{array}$} & \multirow{2}{*}{$\mathrm{C}$} & -0.0046 & -0.0127 & -0.0025 \\
\hline & & $(0.5020)$ & $(0.0981)$ & $(0.7163)$ \\
\hline & \multirow{2}{*}{$\mathrm{RE}(-1)$} & 0.5534 & 0.5515 & 0.5520 \\
\hline & & $(0.0000)$ & $(0.0000)$ & $(0.0000)$ \\
\hline & \multirow{2}{*}{ SATURDAY } & 0.0202 & 0.0210 & 0.0226 \\
\hline & & $(0.1305)$ & $(0.1158)$ & $(0.1264)$ \\
\hline & \multirow{2}{*}{ WEDNESDAY } & 0.0472 & 0.0473 & 0.0482 \\
\hline & & $(0.0003)$ & $\begin{array}{l}(0.0003) \\
0.0418\end{array}$ & $(0.0002)$ \\
\hline & GARCH & - & $(0.0471)$ & - \\
\hline \multirow{8}{*}{$\begin{array}{l}\text { Variance } \\
\text { Equation }\end{array}$} & \multirow[b]{2}{*}{$\mathrm{C}$} & 0.0373 & 0.0400 & 0.0270 \\
\hline & & $(0.0007)$ & $(0.0007)$ & $(0.0030)$ \\
\hline & \multirow[t]{2}{*}{$\operatorname{RESID}(-1)^{\wedge} 2$} & 1.3991 & 1.4446 & 1.2057 \\
\hline & & $\begin{array}{l}(0.0019) \\
0.4282\end{array}$ & $\begin{array}{l}(0.0020) \\
0.4103\end{array}$ & $\begin{array}{l}(0.0005) \\
0.4249\end{array}$ \\
\hline & GARCH(-1) & $(0.0000)$ & $(0.0000)$ & $(0.0000)$ \\
\hline & $\mathrm{RE}(-1)$ & - & - & $\begin{array}{l}0.0484 \\
(0.0504)\end{array}$ \\
\hline & SATURDAY & - & - & 0.0447 \\
\hline & WEDNESDAY & - & - & $\begin{array}{l}0.0074 \\
(0.6713)\end{array}$ \\
\hline
\end{tabular}

\subsection{Weekend Effect within the Monthly Effect}

Here, returns on Saturdays and Wednesdays in the first half and the second half of the month are separately investigated in order to examine the weekend effect as the days elapse. As the results show, data obtained for Saturdays and Wednesdays of the second half are not significant and valid. In contrast, coefficients for Saturday and Wednesday variables in the first half are significant, positive for all three models of $\mathrm{GARCH}_{(1-1)}, \mathrm{GARCH}-\mathrm{M}$, and Modified $\mathrm{GARCH}_{(1-1)}$. Also, the return variable has a significant, positive effect on returns over the same period with just one break (Table 2).

Table 2. Weekend effect within the first half of the month

\begin{tabular}{|c|c|c|c|c|}
\hline & & $\operatorname{GARCH}(1,1)$ & GARCH-M & $\begin{array}{c}\text { MODIFIED } \\
\operatorname{GARCH}(1,1)\end{array}$ \\
\hline \multirow[t]{5}{*}{$\begin{array}{l}\text { Return } \\
\text { Equation }\end{array}$} & $\mathrm{C}$ & $\begin{array}{l}-0.0014 \\
(0.8060)\end{array}$ & $\begin{array}{l}-0.0095 \\
(0.1569)\end{array}$ & $\begin{array}{l}0.0005 \\
(0.9311)\end{array}$ \\
\hline & $\mathrm{RE}(-1)$ & $\begin{array}{l}0.5488 \\
(0.0000)\end{array}$ & $\begin{array}{l}0.5468 \\
(0.0000)\end{array}$ & $\begin{array}{l}0.5486 \\
(0.0000)\end{array}$ \\
\hline & SATURDAYFIRST & $\begin{array}{l}0.0413 \\
(0.0203)\end{array}$ & $\begin{array}{l}0.0429 \\
(0.0161)\end{array}$ & $\begin{array}{l}0.0446 \\
(0.0160)\end{array}$ \\
\hline & WEDNESDAYFIRST & $\begin{array}{l}0.0555 \\
(0.0008)\end{array}$ & $\begin{array}{l}0.0554 \\
(0.0008)\end{array}$ & $\begin{array}{l}0.0571 \\
(0.0009)\end{array}$ \\
\hline & GARCH & - & $\begin{array}{l}0.0421 \\
(0.0459)\end{array}$ & - \\
\hline \multirow[t]{6}{*}{$\begin{array}{l}\text { Variance } \\
\text { Equation }\end{array}$} & $\mathrm{C}$ & $\begin{array}{l}0.0363 \\
(0.0006)\end{array}$ & $\begin{array}{l}0.0388 \\
(0.0007)\end{array}$ & $\begin{array}{l}0.0383 \\
(0.0004)\end{array}$ \\
\hline & $\operatorname{RESID}(-1)^{\wedge} 2$ & $\begin{array}{l}1.4014 \\
(0.0018)\end{array}$ & $\begin{array}{l}1.4473 \\
(0.0019)\end{array}$ & $\begin{array}{l}1.2823 \\
(0.0009)\end{array}$ \\
\hline & GARCH(-1) & $\begin{array}{l}0.4310 \\
(0.0000)\end{array}$ & $\begin{array}{l}0.4142 \\
(0.0000)\end{array}$ & $\begin{array}{l}0.4147 \\
(0.0000)\end{array}$ \\
\hline & $\mathrm{RE}(-1)$ & - & - & $\begin{array}{l}0.0540 \\
(0.0467)\end{array}$ \\
\hline & SATURDAYFIRST & - & - & $\begin{array}{l}0.0030 \\
(0.8888)\end{array}$ \\
\hline & WEDNESDAYFIRST & - & - & $\begin{array}{l}0.0037 \\
(0.8804)\end{array}$ \\
\hline
\end{tabular}




\subsection{Monthly Effect}

According to Table 3, for all research models, coefficients for Day and Bahman variables, indicating the calendar effects at the end of the year, are purely negative and insignificant. On the other hand, Farvardin, Mordad, and Shahrivar show significant, positive effects on the return. The return variable has a significant, positive effect on returns over the same period with just one break. Therefore, it is clear that the stock market has a relatively good performance in the first half of the year, while this will be declined toward the last months of the year. The results verify the Farvardin effect matching the January effect.

Table 3. Month of the year effect

\begin{tabular}{|c|c|c|c|c|}
\hline & & $\operatorname{GARCH}(1,1)$ & GARCH-M & $\begin{array}{c}\text { MODIFIED } \\
\text { GARCH }(1,1)\end{array}$ \\
\hline \multirow[t]{14}{*}{ Return Equation } & $\mathrm{RE}(-1)$ & $\begin{array}{l}0.5187 \\
(0.0000)\end{array}$ & $\begin{array}{l}0.5192 \\
(0.0000)\end{array}$ & $\begin{array}{l}0.5152 \\
(0.0000)\end{array}$ \\
\hline & AABAN & $\begin{array}{l}0.0071 \\
(0.6765)\end{array}$ & $\begin{array}{l}-0.0004 \\
(0.9774)\end{array}$ & - \\
\hline & AAZAR & $\begin{array}{l}-0.0159 \\
(0.3899)\end{array}$ & $\begin{array}{l}-0.0254 \\
(0.1813)\end{array}$ & - \\
\hline & BAHMAN & $\begin{array}{l}-0.0249 \\
(0.1116)\end{array}$ & $\begin{array}{l}-0.0297 \\
(0.0622)\end{array}$ & $\begin{array}{l}-0.0244 \\
(0.0907)\end{array}$ \\
\hline & ESFAND & $\begin{array}{l}-0.0017 \\
(0.9271)\end{array}$ & $\begin{array}{l}-0.0064 \\
(0.7441)\end{array}$ & $\begin{array}{l}0.0023 \\
(0.9060)\end{array}$ \\
\hline & FARVARDIN & $\begin{array}{l}0.0643 \\
(0.0002)\end{array}$ & $\begin{array}{l}0.0588 \\
(0.0008)\end{array}$ & $\begin{array}{l}0.0620 \\
(0.0001)\end{array}$ \\
\hline & MEHR & $\begin{array}{l}-0.0143 \\
(0.4211)\end{array}$ & $\begin{array}{l}-0.0226 \\
(0.2118)\end{array}$ & $\begin{array}{l}-0.0195 \\
(0.3594)\end{array}$ \\
\hline & DAY & $\begin{array}{l}-0.0358 \\
(0.0159)\end{array}$ & $\begin{array}{l}-0.0405 \\
(0.0074)\end{array}$ & $\begin{array}{l}-0.0381 \\
(0.0074)\end{array}$ \\
\hline & ORDIBEHESHT & $\begin{array}{l}0.0059 \\
(0.7265)\end{array}$ & $\begin{array}{l}0.0016 \\
(0.9249)\end{array}$ & $\begin{array}{l}0.0032 \\
(0.7872)\end{array}$ \\
\hline & KHORDAD & $\begin{array}{l}0.0204 \\
(0.1973)\end{array}$ & $\begin{array}{l}0.0156 \\
(0.3331)\end{array}$ & $\begin{array}{l}0.0214 \\
(0.1920)\end{array}$ \\
\hline & TIR & $\begin{array}{l}0.0233 \\
(0.2292)\end{array}$ & $\begin{array}{l}0.0153 \\
(0.4355)\end{array}$ & $\begin{array}{l}0.0280 \\
(0.2191)\end{array}$ \\
\hline & MORDAD & $\begin{array}{l}0.0522 \\
(0.0361)\end{array}$ & $\begin{array}{l}0.0418 \\
(0.0973)\end{array}$ & $\begin{array}{l}0.0597 \\
(0.0634)\end{array}$ \\
\hline & SHAHRIVAR & $\begin{array}{l}0.0642 \\
(0.0014)\end{array}$ & $\begin{array}{l}0.0542 \\
(0.0076)\end{array}$ & $\begin{array}{l}0.0511 \\
(0.0407)\end{array}$ \\
\hline & GARCH & - & $\begin{array}{l}0.0323 \\
(0.0922) \\
\end{array}$ & - \\
\hline \multirow[t]{10}{*}{ Variance Equation } & $\mathrm{C}$ & $\begin{array}{l}0.0330 \\
(0.0017)\end{array}$ & $\begin{array}{l}0.0361 \\
(0.0020)\end{array}$ & $\begin{array}{l}0.0575 \\
(0.0042)\end{array}$ \\
\hline & $\operatorname{RESID}(-1)^{\wedge} 2$ & $\begin{array}{l}1.5109 \\
(0.0043)\end{array}$ & $\begin{array}{l}1.5768 \\
(0.0049)\end{array}$ & $\begin{array}{l}1.3043 \\
(0.0006)\end{array}$ \\
\hline & GARCH(-1) & $\begin{array}{l}0.4507 \\
(0.0000)\end{array}$ & $\begin{array}{l}0.4308 \\
(0.0000)\end{array}$ & $\begin{array}{l}0.3647 \\
(0.0000)\end{array}$ \\
\hline & $\mathrm{RE}(-1)$ & - & - & - \\
\hline & BAHMAN & - & - & $\begin{array}{l}-0.0307 \\
(0.0987)\end{array}$ \\
\hline & ESFAND & - & - & $\begin{array}{l}-0.0163 \\
(0.3894)\end{array}$ \\
\hline & FARVARDIN & - & - & $\begin{array}{l}-0.0321 \\
(0.0847)\end{array}$ \\
\hline & MEHR & - & - & $\begin{array}{l}0.0053 \\
(0.8264)\end{array}$ \\
\hline & DAY & - & - & $\begin{array}{l}-0.0276 \\
(0.1451)\end{array}$ \\
\hline & ORDIBEHESHT & - & - & $\begin{array}{l}-0.0436 \\
(0.0202)\end{array}$ \\
\hline
\end{tabular}




$\begin{array}{llll}\text { KHORDAD } & - & - & -0.0181 \\ & & & (0.3533) \\ \text { TIR } & - & - & 0.0119 \\ & & & (0.6409) \\ \text { MORDAD } & - & - & 0.0569 \\ & & & (0.1104) \\ \text { SHAHRIVAR } & - & - & -0.0296 \\ & & & (0.3775)\end{array}$

\subsection{Seasonal Effect}

Using the three models reveals that the spring and the summer have significant, positive effects on the TSE, while the winter shows a negative and significant effect. The return variable has a significant, positive effect on returns over the same period with just one break (Table 4).

Table 4. Season of the year effect

\begin{tabular}{|c|c|c|c|c|}
\hline & & $\operatorname{GARCH}(1,1)$ & GARCH-M & $\begin{array}{c}\text { MODIFIED } \\
\text { GARCH }(1,1)\end{array}$ \\
\hline \multirow[t]{6}{*}{ Return Effect } & $\mathrm{RE}(-1)$ & $\begin{array}{l}0.5304 \\
(0.0000)\end{array}$ & $\begin{array}{l}0.5303 \\
(0.0000)\end{array}$ & $\begin{array}{l}0.5303 \\
(0.0000)\end{array}$ \\
\hline & BAHAR & $\begin{array}{l}0.0286 \\
(0.0042)\end{array}$ & $\begin{array}{l}0.0230 \\
(0.0278)\end{array}$ & $\begin{array}{l}0.0364 \\
(0.0001)\end{array}$ \\
\hline & PAEIZ & $\begin{array}{l}-0.0077 \\
(0.4534)\end{array}$ & $\begin{array}{l}-0.0167 \\
(0.1242)\end{array}$ & - \\
\hline & ZEMESTAN & $\begin{array}{l}-0.0205 \\
(0.0348)\end{array}$ & $\begin{array}{l}-0.0258 \\
(0.0110)\end{array}$ & $\begin{array}{l}-0.0555 \\
(0.0000)\end{array}$ \\
\hline & TABESTAN & $\begin{array}{l}0.0435 \\
(0.0004)\end{array}$ & $\begin{array}{l}0.0330 \\
(0.0103)\end{array}$ & $\begin{array}{l}0.0872 \\
(0.0000)\end{array}$ \\
\hline & GARCH & - & $\begin{array}{l}0.0355 \\
(0.0739)\end{array}$ & - \\
\hline \multirow{9}{*}{$\begin{array}{l}\text { Variance } \\
\text { Effects }\end{array}$} & & 0.0362 & 0.0399 & 0.0725 \\
\hline & $\mathrm{C}$ & $(0.0012)$ & $(0.0015)$ & $(0.0008)$ \\
\hline & $\operatorname{RESID}(-1)^{\wedge} 2$ & $\begin{array}{l}1.4732 \\
(0.0033)\end{array}$ & $\begin{array}{l}1.5423 \\
(0.0038)\end{array}$ & $\begin{array}{l}1.2316 \\
(0.0006)\end{array}$ \\
\hline & $C \triangle \mathrm{P} C H(1)$ & 0.4370 & 0.4144 & 0.3419 \\
\hline & GAKCH(-1) & $(0.0000)$ & $(0.0000)$ & $(0.0000)$ \\
\hline & $\mathrm{RE}(-1)$ & - & - & $\begin{array}{l}0.0711 \\
(0.0232)\end{array}$ \\
\hline & BAHAR & - & - & $\begin{array}{l}-0.0471 \\
(0.0082)\end{array}$ \\
\hline & ZEMESTAN & - & - & $\begin{array}{l}-0.0314 \\
(0.0489)\end{array}$ \\
\hline & TABESTAN & - & - & $\begin{array}{l}0.0219 \\
(0.2988)\end{array}$ \\
\hline
\end{tabular}

\section{Discussion and Conclusion}

6.1 According to the results estimated, there is a significant, positive relationship between the stock return and the dummy variable of Wednesday as the last working day of the week. This relationship is stronger than Saturday. Hence, the current study confirms the weekend effect which has been already confirmed in the US where the last trading day has a positive return higher than the rest days of the week. The difference is that now, the stock market shows a positive return on Saturdays, indicating a greater purchase volume than selling volume by investors on the same days. This is inconsistent with other studies conducted on foreign stock markets which report a negative return on the first working day of the week.

One possible reason may be related to differences in information flows in the weekend with the other days, since companies often hide bad news about their activities till the end of the week, and provide news about dividend yields or positive return modifications into the markets during the week.

Another reason for the weekend effect can be the weaker trading pattern of institutional investors than individual 
investors on Saturdays.

6.2 As the results showed, regarding the first hypothesis, there are significant, positive relationships between Saturdays and Wednesdays in the first half of the month and the market return, and Wednesdays provide higher return than Saturdays. Therefore, the presence of the weekend effect can be verified in the first half. Examining the second half, such effect was not significant at the early stages of data research, so the weekend effect of the second half of the month could not be examined and compared on the stock return.

In order to study what causes the weekend effect in the second half insignificant, the return levels on the same days were investigated individually during 2004 to 2010. It can be concluded that such asymmetric relationship may be the product of the necessity of brokerage loan settlement since 2009 which occurs on the last Wednesday of the month, as well as of the requirement to report the Exchange Clearing House, which was not of great importance before 2009.

6.3 However, the results indicated significant, positive relationships between the months of Farvardin, Mordad, and Shahrivar and the return; also negative and significant relationships between Day and Bahman and the return. Therefore, the January effect matching the Farvardin effect at the TSE was confirmed. Because Farvardin as the first month of the year has a higher return than other months. This can be explained by selling losers by institutional investors at the end of the year in order to improve the year-end portfolio. Alternatively, the lack of individual investors (as the big sellers) and easily modified prices also increase the return in Farvardin. Although this issue may be investigated from behavioral and real aspects; during the early days of a new year, individuals have less anxiety and good environmental factors influence their behaviors and make them more optimistic so that people consider good changes in economic situations and stock prices are increased. But the real feature is that shareholders are more informed about cash flows of companies and present in annual meetings, this may attract investors to purchase stocks.

Among reasons for negative returns in Day and Bahman are that these months synchronize with the end of year in the Christian calendar, and Iranian market depends upon world prices. Also, financial statements (unaccounted during nine months) are provided on Day and this may show some conservative tendency of companies, the behavioral cause is the beginning of a cold season and changing in weather conditions which may lead to some weakness and debility in individuals.

6.4 Based on the finding, the summer and the winter show the highest and lowest return levels, respectively.

A good performance in capital markets in the first half of the year is related to holding annual meetings and the fiscal year ended in many companies. Since companies mostly hold their annual meetings in the late of Khordad and Tir, and after divining cash yields and good news, they face with increased stock prices. Furthermore, companies usually announce the predictions for each stock return conservatively at the end of the past fiscal year, so three-month reports in the first half of the current year enable positive and predictable modifications which is, in turn, another reason for an increasing growth in prices in the summer rather than the spring. Note that the second half of the year provides investment opportunities with less return in the market, as the findings revealed.

\section{References}

Ariel, R. (1987). A monthly effect in stock returns. Journal of Financial Economics, 18, 161-174. http://dx.doi.org/10.1016/0304-405X(87)90066-3

Berument, H., \& Kiymaz, H, (2001). The day of the week effect on stock market volatility. Journal of Economics and Finance, 25(2), 181-192. http://dx.doi.org/10.1007/BF02744521

Cao, Qi. (2006). The calendar effect on A-Share index return in chinese stock market. The university of Nottingham.

Cross, F. (1973). The behavior of stock prices on Fridays and Mondays. Financial Analysts Journal, November/December, 67-69. http://dx.doi.org/10.2469/faj.v29.n6.67

French, K. (1980). Stock returns and the weekend effect. Journal of Financial Economics, 8, 55-69. http://dx.doi.org/10.1016/0304-405X(80)90021-5

Gao, L. (2005). Calendar effect on Chinese stock market. Annals of Economics \& Finance, 6, 75-68.

He, X. G., Xu, Y. C., \& Wu, D. S. (2005). Month of the year effects in the Chinese A share stock markets. The Research Center of Nankai Corporate Governance (In Chinese).

Lakonishok, J., \& Levi, M. (1982). Weekend effect on stock returns. Journal of Finance, 37, 883-889. http://dx.doi.org/10.1111/j.1540-6261.1982.tb02231.x 
Lakonishok, J., \& Maberly, E, (1990). The weekend effect: Trading patterns of individual and institutional investors. Journal of Finance, 40, 231-243. http://dx.doi.org/10.1111/j.1540-6261.1990.tb05089.x

Liano, Kartono, \& Lindley, James T. (1995). An analysis of the weekend effect within the monthly effect. Review of Quantitative Finance and Accounting, 5, 419-426.

Miller, E. (1988). Why a weekend effect. Journal of Portfolio Management, 14(4), 43-49. http://dx.doi.org/10.3905/jpm.1988.409174

Mills, T. C., \& Coutts, J. A. (1995). Calendar effects in the London stock exchange FTSE indices. The European Journal of Finance, 1, 79- 93. http://dx.doi.org/10.1080/13518479500000010

Sias, R. W., \& Starks, L. T. (1995). The day-of-the-week anomaly: The role of institutional investors. Financial Analysts Journal, 51(3), 58-67. http://dx.doi.org/10.2469/faj.v51.n3.1906

Wang, K., Li, Y. M., \& Erickson, J. (1997). A new look at the Monday effect. Journal of Finance, 52(5), 2171-2186. http://dx.doi.org/10.1111/j.1540-6261.1997.tb02757.x

Wong, K. A., \& Ho, H. D. D. (1986). The weekend effect on stock returns in Singapore. Hong Kong Journal of Business Management, 4, 31-50. 